\title{
WHOLESALE CITY DISTRIBUTION OF FARM PRODUCTS
}

\author{
By Frank G. Urner, \\ Editor, New York Produce Review.
}

I have been urged by the editor of The Annals to discuss the function of the produce commission merchant. It will be impossible to do more than scratch the surface of the subject. The commission merchant is, in many lines, becoming so amalgamated with other classes of distributors that he must be considered in relation to the whole system of distribution. So I have changed the title and shall endeavor in as few words as possible, to set forth some of the facts, feeling that no adequate discussion can be given in so brief a paper.

The directness of movement of farm products to consumers depends largely upon the location of the consumers in relation to the sources of an adequate supply. Farmers can market a small part of their productions directly to consumers in their immediate neighborhood, and through only one intermediate agency in nearby towns. But the great centers of population must draw their supplies from great distances and the distribution here involves the necessary services of a larger number of agencies although in the development of modern business systems these may be more or less combined under a central head and management.

The number of agencies required in the city distribution of farm products depends upon the magnitude of the population, the diversity of its wants as to qualities and service, and the degree to which the system of distribution is developed; also upon the character of the various products.

In a great city, drawing its supplies from a territory as wide as the nation, and from foreign countries, individual dealing in small quantities between producers and consumers is manifestly impossible as an economic proposition applying to the general supply and demand. For economical transportation the products must be, as a rule, shipped in car lots, often under refrigeration. In some instances this may be done by the producer but many articles are raised in smaller quantity and must be amalgamated and prepared for shipment by separate business enterprise. Upon arrival in the great cen- 
ters of consumption consignments must, as a rule, be divided into smaller quantities as needed by retail distributors and separated into different grades so that each may be directed to an appropriate channel of outlet. There is manifestly a need here for a class of wholesale receivers and the directness with which the products can pass from them to the retailer depends largely upon the character of the goods, the manner of packing and the reliability as to uniform quality. Retailers ordinarily buy a great variety of kinds of produce but comparatively small quantities of each at a time, owing to their perishability; and they demand uniformity of quality so far as it is possible to obtain it, in order to satisfy their customers. Retailers can and do buy some articles of farm produce from the first hand receivers or importers but the greater part of the city supply of most descriptions is of irregular quality and requires to be rehandled and graded in order to make it acceptable to retailers. To do this is the function of the wholesale jobber. We have, therefore, three agencies of city distribution, considering the great bulk of the farm products going into city consumption - the wholesale receiver, the jobber, and the retailer.

Primarily, as the cities grew to a magnitude demanding these agencies, the lines of demarkation between them were quite distinct, and of the wholesale receivers, especially those engaged in the receipt and sale of domestic productions, most were commission merchants, acting solely as agents for producers or shippers who bought from the latter at interior points. Thirty years ago most of the wholesale receiving houses handled the great majority of the farm products in a purely agential capacity and the charge for selling wholesale lots to jobbers, in town or out, was usually 10 per cent for fruit and vegetables and 5 per cent for butter, cheese, eggs and poultry.

As the years have passed, however, changes have occurred in the character of the business done by a large part of the wholesale distributors, under the stress of a normal competition which constantly tends to grind out of the distributing machinery all unnecessary factors. Under this competition the lines of demarkation between wholesale receivers and jobbers have become indefinite and are tending toward obliteration in respect to all goods so graded and packed at primary points as to satisfy the demands of dealers nearer to the point of consumption. Jobbers, in the effort to obtain supplies more cheaply, have reached out to primary sources of supply, over the heads of the wholesale receivers; and the latter, in order to maintain their 
hold upon supplies, have reached out over the heads of jobbers for outlets to retailers, so that the two classes of trade, formerly distinct, have tended toward a unification. But in respect to a large part of the farm products, especially such as are of the most perishable nature, this more direct movement has not yet become possible, and at the present time we find in the large markets not only commission merchants and jobbers but also many wholesalers who perform both functions, and many who besides acting as agents for some producers and shippers deal also in the products for their own account.

There is, of course, a material difference in the principle of business involved in the commission and jobbing trades. The former is based upon agency, the merchant handling the property of other owners and deriving his recompense from a definite percentage charge against the proceeds of his sales; the latter is a merchandising proposition in which the goods dealt in are bought and sold, the recompense being derived from such profit as may be obtainable. Theoretically the two forms of distribution are not compatible in a single house for the value of an agent's services to his patrons is lessened by the personal interest that arises from his dealings, for his own account, as owner, in the same class of goods. But the wholesale distributing trade is now in this somewhat anomalous condition. Wholesale jobbers, whose normal function is to buy, assort and sell in broken lots, when drawing supplies from primary sources, widely scattered and often distant, are often obliged to resort to some means of settling values on consignments other than the separate negotiation as to the price terms usually normal to purchase and sale; and commission merchants, under the stress of competition with more direct outlets, and a gradual reduction in the charges for purely agential services, have come to depend at least partially upon the profits to be realized from merchandising. Purchase and sale for own account on the part of nominal commission merchants have also been encouraged by the demands of producers and shippers for immediate returns and the competition to render such returns in many cases before the goods could be sold.

The change from a purely agential handling of farm products by first hand receivers to a merchandising system, or to a mixed system in which goods are handled both on commission and for own account, has doubtless been favored also by the development of cold storage preservation; for the speculative element inherent in this 
business, while open to all, is most naturally undertaken by handlers who are best fitted through the broadness of their connections and experience to judge of market conditions and the relation of current to prospective values.

While the mixture of agential and merchandising business in wholesale, first hand distribution is theoretically unsound it seems to be an inevitable accompaniment of the gradual progress toward the more direct movement of products from producer to consumer, in the final development of which the agency feature is likely ultimately to disappear, or to be confined to the most perishable commodities in which two wholesale classes of distributors may continue essential.

It is probably a safe conclusion that the number of distributing agencies cannot be lessened any faster, nor to any greater extent, than is naturally being done through the forces of business competition; and that such possible elimination is limited by the amalgamation of the wholesale receiving and jobbing trades which is already largely effected and which is being extended as to products of the less perishable nature as rapidly as improvements in their uniformity of quality permit.

Furthermore, while there must always be a wholesale distributing agency in large cities between the producer or shipper and the retailer, there is opportunity for the performance of all the distributive functions between wholesale receipt and sales to consumers-even of all between producers and consumers--by single generalized establishments, either proprietary or coöperative. The opportunity for this important development has not lain fallow but has been largely put into effect in business enterprises that are constantly being extended, and in which all the necessary distributive functions are performed, including the collection of products from producers at widely separated points, the preparation for shipment, the wholesale receipt in centers of congested population, the separation into uniform grades and the final distribution in small lots to consumers through chains of retail stores. Such establishments have an economic advantage under efficient systemization and management which redounds to the advantage of consumers and producers as soon as they become numerous enough to create an equality of competition and so long as such competition is maintained.

So far this development of complete amalgamation of distributive functions has been carried the furthest in the less perishable 
kinds of farm products, or those whose preservation has been extended by the use of refrigeration. There would seem, however, to be opportunity for further development of similar character in the distribution of even the more perishable productions. But however the growing hand of business enterprise may grasp the various functions of distribution and combine them under a central management, the wholesale receipt and classification and the retail distribution must remain as distinct departments of such enterprises, and, because of the great magnitude of the traffic, it will doubtless be long before individual business efforts, specialized in either department, will cease to be profitable under careful management. The wholesale commission merchant, also, will continue to perform a useful and necessary function so long as large quantities of farm products reach the market in widely irregular quality and condition, so as to require variable channels of outlet. 